\title{
Environmental impact on ectocochleate cephalopod reproductive strategies and the evolutionary significance of cephalopod egg size
}

\author{
VLADIMIR V. LAPTIKHOVSKY, MIKHAIL A. ROgOV, SVETLANA V. NIKOLAEVA \& \\ ALEXANDER I. ARKHIPKIN
}

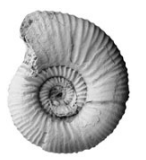

Published data on initial chamber (protoconch) diameter in 507 species, and embryonic shell (ammonitella) diameter in 231 species of Ammonoidea, and embryonic shell (nauta) diameters for 132 species of coiled Nautiloidea, were used to examine evolutionary change in ectocochleate cephalopod reproductive strategies. Palaeotemperatures were found to be a key factor influencing historical changes in the evolution of egg size in ammonoids and nautiloids. A negative relationship was found between egg size and warming of the Earth's climate. Factors related to habitat were also important; in general egg size was larger in cold-water cephalopods. Egg size in Lytoceratina and Phylloceratina in the deep waters of the upper continental slope was much larger than in epipelagic Scaphitidae, as in modern fish and squids. Small eggs and high evolutionary rates helped ammonoids to colonise new habitats and develop high biological diversity, but involved them in planktonic food webs making them more vulnerable to abiotic variability (e.g., climatic changes), ultimately leading to their extinction. Large eggs helped nautiloids to persist through geological history, but at the cost of lower biological diversity, lower evolutionary rates and restricted options for colonising new habitats. Large-egged species such as nautiloids are more vulnerable to ecological, biotic disasters such as the appearance of new predators, including modern fishery. Independence from the planktonic food web is likely to be very important for a taxon's long-term survival over evolutionary history, as demonstrated also by Coelacanthiformes and Elasmobranchia. $\bullet$ Key words: Ammonoidea, Nautiloidea, reproductive strategy, mass extinction, climate change, egg.

LAPTIKHOVsky, V.L., Rogov, M.A., NikOlaEva, S.E. \& ARKHIPKIN, A.I. 2013. Environmental impact on ectocochleate cephalopod reproductive strategies and the evolutionary significance of cephalopod egg size. Bulletin of Geosciences 88(1), 83-93 (4 figures, 1 table, online supplementary material - Appendices 1-3). Czech Geological Survey, Prague. ISSN 1214-1119. Manuscript received February 2, 2012; accepted in revised form June 19, 2012; published online November 28, 2012; issued December 6, 2012.

Vladimir V. Laptikhovsky, Falkland Islands Government Fisheries Department, Stanley, FIQQ 1ZZ, Falkland Islands; vlaptikhovsky@fisheries.gov.fk•Mikhail A. Rogov, Geological Institute of Russian Academy of Sciences, Pyzhevskii Lane 7, Moscow, 119017, Russia; russianjurassic@gmail.com•Svetlana V. Nikolaeva, Paleontological Institute, Russian Academy of Sciences, Moscow, 117997, Russia; 44svnikov@mail.ru・Alexander I. Arkhipkin, Falkland Islands Government Fisheries Department, Stanley, FIQQ 1ZZ, Falkland Islands; aarkhipkin@fisheries.gov.fk

Reproductive strategy is an important choice that species face continuously during their evolutionary history. A trade-off exists between fecundity and egg size (numbers $v s$ "quality" of hatchling) because generative production in every species is restricted by body size, available food and longevity (Kasyanov 1999). Understanding these competing strategies led to the idea of $r$ - and $K$-selection in life histories (MacArthur \& Wilson 1967, Pianka 1970). It involves a bet-hedging concept that assumes that maximizing strategies are more advantageous in stable and predictable environments where variance is minimal, while minimizing strategies can enhance long-term fitness in periodically variable environments. Because of this, $r$-populations tend to inhabit unpredictable or ephemeral habitats, whereas $K$-populations tend to inhabit environments that are relatively stable (Slatkin 1974, Frank \& Slatkin 1990).

The $r$ - and $K$-strategy model is no longer considered to be a satisfactory framework for the entire life history theory, because a species' life history also involves parameters such as longevity, growth rate, and body size to name but a few (Stearns 1992). However, it is still a useful tool to describe the relative position of a species' strategy within a taxon-specific $r-K$ continuum, particularly in respect to egg size when other life history parameters are considered to be relatively equal.

The coiled ectocochleate cephalopods Ammonoidea and Nautiloidea were abundant and diverse in Late 
Palaeozoic and Mesozoic seas. Both taxa co-existed and co-evolved over about 330 millions years. Ammonoidea appeared and instantly occupied the water column during the Devonian nekton revolution (Klug et al. 2010) and almost immediately displayed a variety of life styles (Klug 2001). Nautiloidea appeared in the Ordovician and persist to the present day. Ammonoidea produced smaller eggs with smaller offspring (Landman 1988), and can be considered $r$-strategists compared to Nautiloidea. They also had higher rates of origination of genera and families and higher biological diversity, as well as shorter average duration of genera compared to coiled nautiloidea (Teichert 1967, Ward 1980, Stephen \& Stanton 2002, Wani 2011), though this still has to be demonstrated with respect to speciation and individual species longevity. Both ammonoids and nautiloids were active swimming marine non-herbivorous molluscs with external shell protection and a mechanism to maintain neutral buoyancy, though shell shape generally differed between the two groups (Ward 1980). Their evolutionary fate was also different; the Nautiloidea successfully survived all major extinctions despite lower biological diversity and slower recovery, i.e. fewer variants to meet drastic changes in environment. Conversely, the morphologically and ecologically diverse Ammonoidea narrowly passed through a number of mass extinction events before eventually becoming extinct at the end of the Cretaceous. As underlined by Wani (2011 and references within) this contradicts a generally accepted point of view that species with planktonic eggs and larvae - so wider dispersal - exhibit lower probability of speciation and extinction, and therefore lower species richness.

This paper aims to investigate the history of nautiloid and ammonoid reproductive strategies throughout their parallel evolution from the late Palaeozoic onwards, and to determine potential environmental factors influencing egg size (and hence offspring viability), which "is one character that can be used to estimate other life-history characters" (Jaeckle 2001). This is particularly true for ammonoids in which the strategy of early ontogenetic stages (expressed in protoconch and ammonitella size, shape, and ornament) was crucial for survival through extinction events and consequent quick radiation of survivors in contrast to slow recovery of nautiloid fauna (House 1996, Manda \& Turek 2011).

\section{Material and methods}

To describe evolutionary changes in ectocochleate cephalopod reproductive strategies we used published data on the diameter of initial chamber (so-called "protoconch", though not homologous to that of Gastropods) (PD, mm) in 508 species of Ammonoidea, and 231 measurements of embryonic shell (ammonitella) diameter (AD, mm) were also used (a total of 524 species; Appendix 1). The diameter of the nauta (the embryonic shell with a nepionic constriction at its aperture) (ND, mm) was found for 134 species of coiled Nautiloidea (Appendix 2). The dataset we compiled on extinct cephalopod reproductive features (Appendix 3) was about twice as large as the largest previous such dataset (267 ammonite species in De Baets et al. 2012). All sizes given were assumed to be the median between minimum and maximum values, which is how they have typically been reported. The size was taken as a single value when a single embryonic shell was measured. We assume that egg size of ammonoids was similar to that of the ammonitella, not of the protoconch (House 1996, Landman et al. 1996). However, we used PD because primary data were more abundant, and both $\mathrm{AD}$ and $\mathrm{PD}$ were closely related $(\mathrm{AD}=1.63768 \mathrm{PD}+0.1063$; Spearman $\mathrm{r}=$ $0.873, \mathrm{P}<0.0001$ - our data set). Similarly, egg size of extinct nautiloids was assumed to be equal to the size of the nauta, as in extant Nautilus and Allonautilus. All statistical analyses were done using GraphPad Prism ver. 4.03 2005, and Brodgar Statistical Software ver. 2.5.1. Boundaries of chronostratigraphic units were taken from Gradstein et al. (2008). Jurassic and Cretaceous ammonites were arbitrarily divided into two major groups. 1) Tropical and subtropical species that included fossils collected well away from polar areas, and that lived at temperatures more or less similar to those in recent seas between latitudes $40^{\circ} \mathrm{N}$ and $40^{\circ} \mathrm{S}$. 2) Temperate species that were collected in the polar areas of that time. Data on latitudinal variability of the Earth's climate were obtained from a range of publications (Kurushin \& Zakharov 1995, Zakharov et al. 1999, Ross et al. 2002, Golonka 2007, Donnadieu et al. 2006, Takashima et al. 2006, Dera et al. 2011, Wierzbowski \& Rogov 1911). Because of uncertainties related to ammonite ontogenetic latitudinal and bathymetric migrations, shell transport by currents, and short-term climate variability during individual geologic epochs, we did not attempt more precise species allocation to particular biogeographic ranges.

\section{Results}

\section{Ammonoids}

Both $\mathrm{PD}$ and $\mathrm{AD}$ varied significantly during the entire 330 million year history of ammonites: from 0.2 to $1.6 \mathrm{~mm}$ (Fig. 1) and from 0.54 to $2.6 \mathrm{~mm}$ respectively. The largest protoconchs were associated with the earliest ammonoids (Fig. 2) from the early and middle Devonian. Protoconch size began to decrease from middle to late Devonian, and in the Mississippian PD was mostly between 0.3 and $0.8 \mathrm{~mm}$ (AD mostly $0.6-1.4 \mathrm{~mm}$ ). From the Mississippian to the Early Triassic mean PD was the lowest in the entire history of ammonoids (Kruskal-Wallis test, $\mathrm{P}<0.0001$; Dunn's 
Vladimir V. Laptikhovsky et al. • Ectocochleate cephalopod reproductive strategies

Figure 1. Historical changes in embryonic shell size in Ammonoidea (A) and Nautiloidea (B).
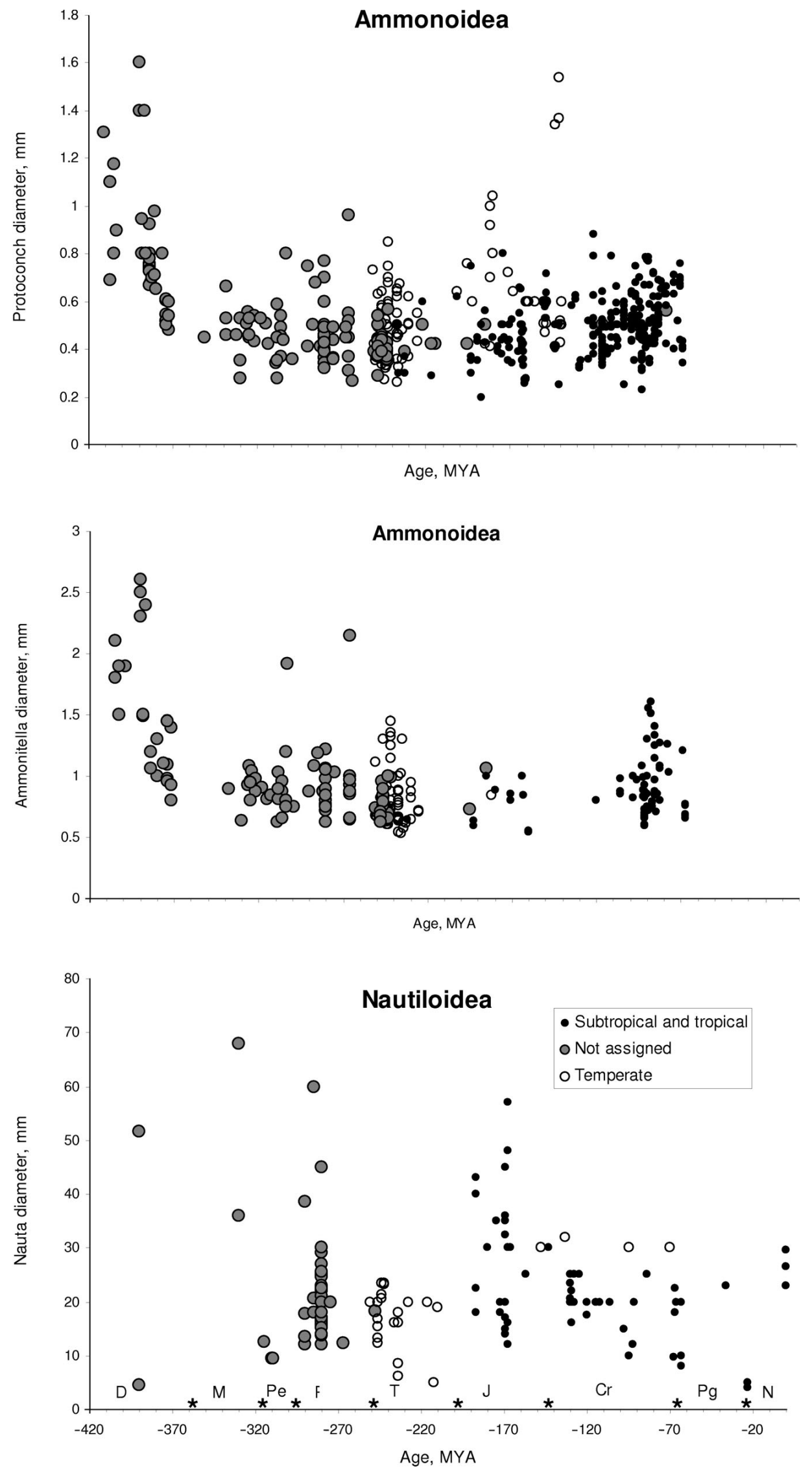

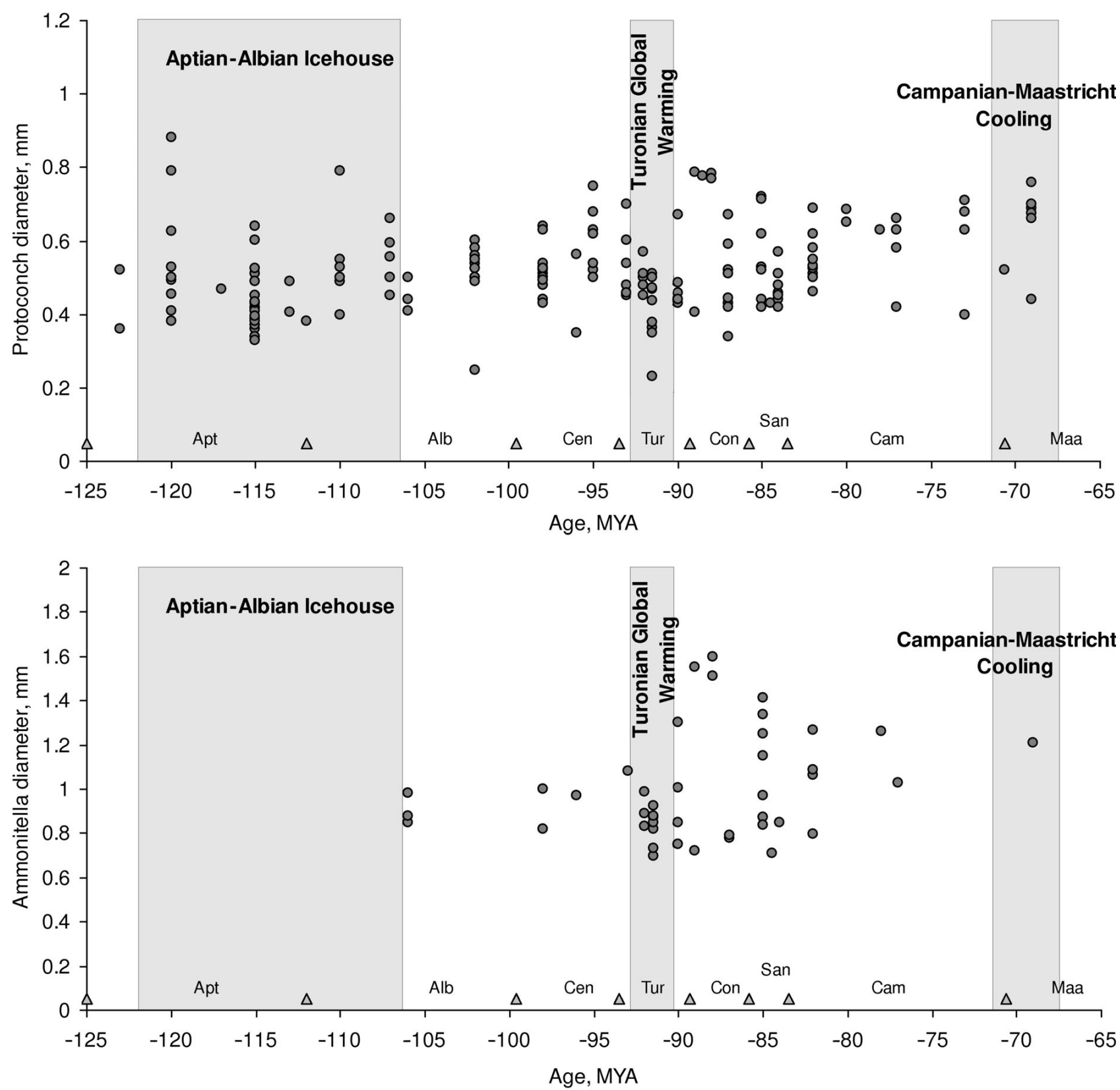

Figure 2. Temporal change of ammonoid protoconch size in Cretaceous.

multiple paired comparison post test, $\mathrm{P}$ from $<0.001$ to $<0.01)$. From the Middle Triassic PD began to increase again until Early Cretaceous. This trend in change of initial shell size (PD) with geological age (MYA) is most evident in temperate ammonites (Pearson $\mathrm{r}=0.51, \mathrm{P}<0.0001$ at $\alpha=0.05$ ), but was relatively weak in tropical and subtropical ammonites (Pearson $\mathrm{r}=0.29, \mathrm{P}<0.0001$ at $\alpha=0.05)$. For an entire combined sample of Mesozoic ammonites this correlation was also statistically significant (Pearson $r$ $=0.20, \mathrm{P}<0.0001$ at $\alpha=0.05)$ but less obvious because of climatic and taxonomic bias. In the Cretaceous, the average PD decreased from the Aptian-Albian $(0.496 \pm 0.027)$ to the Middle-Late Turonian $(0.418 \pm 0.040)$, and then increased again until the Maastrichtian $(0.0569 \pm 0.038)$, Kruskal-Wallis test $(\mathrm{P}<0.0001)$ with Dunn's multiple comparison post-test ( $\mathrm{P}$ from $<0.001$ to $<0.05$; Figs 2, 3).

Cold-water (temperate) ammonoids produced larger protoconchs than tropical-subtropical species [Mean PD 0.70 (confidence, interval, CI 0.61-0.78) vs 0.50 (CI $0.49-0.52)$, Mann Whitney $\mathrm{U}=1726, \mathrm{P}<0.0001$ in a combined Jurassic-Cretaceous sample]. The PD in Cretaceous ammonoids collected around Japan was also inversely related to historical changes in estimated paleotemperatures, Spearman $\mathrm{r}=-0.354, \mathrm{P}=0.002$ (Fig. 4). 
There were also differences between ammonites occurring in different habitats of the same area. Late Cretaceous Phylloceratina, and Lytoceratina from the North Pacific that lived in near-bottom layers over the continental slope (Moriya et al. 2003) produced relatively larger eggs (mean $\mathrm{PD}=$ $0.56 \mathrm{~mm}, \mathrm{AS}=1.06 \mathrm{~mm}, \mathrm{n}=82$ ) than shelf and epipelagic Scaphitidae with an upward orientation of aperture that were adapted to live in upper layers of water column (Seilacher \& Labarbera 1995, Landman et al. 2012) - mean PD $=0.41 \mathrm{~mm}$, mean $\mathrm{AD}=0.73 \mathrm{~mm}(\mathrm{n}=18)$. Differences were significant both between PD (Mann - Whitney, 185, P < 0.0001) and in AD (Mann - Whitney, 59, $\mathrm{P}<0.0001)$.

\section{Nautiloids}

Nauta size in coiled nautiloids was very diverse throughout the Palaeozoic era (Fig. 1), but showed a decrease between the Permian and the Triassic. Further evolution of this feature in Mesozoic temperate seas followed the same pattern as in ammonoids: it increased from the Triassic to the Late Cretaceous (Pearson $\mathrm{r}=0.63, \mathrm{P}=0.0009$ at $\alpha=0.05$ ). However, in tropical and subtropical seas it decreased with time (Fig. 1; Pearson $r=-0.42, \mathrm{P}=0.0009$ at $\alpha=0.05$ ), with a particular drop in the Early Cretaceous. Where comparison was possible, cold-water species were found to produce larger eggs. For example, among the Cenomanian-Maastrichtian nautilids the largest nauta of about $30 \mathrm{~mm}$ was found in polar Cymatoceras yabei from Chukotka (Shimanski 1975) and Eutrephoceras subplicatum from Antarctica (Cichowolski et al. 2005), whereas the remaining tropical and subtropical nautiloids from Middle Asia, Caucasus, south USA and the Far East had embryonic shells of 10-25 (mean 16.9) mm. Even among this warm-water cohort, the largest nauta of $25 \mathrm{~mm}$ was found in a relatively cold-water species - Cymatoceras sp. from Sakhalin (Shimanski 1975). It is also noticeable that nauta size in modern Nautilus and Allonautilus (23-29 mm) that live in the relatively cold climate of the Holocene (as well as far away from surface waters) is larger than those in Cretaceous-Paleogene species that lived in a warmer epoch, even if we omit the unusual $r$-strategist Aturia spp. (8-23 $\mathrm{mm}$ in Eutrephoceras, Hercoglossa, Cimomia, Teichertia, and extinct species of Nautilus; Shimanski 1975, Wani et al. 2011).

\section{Discussion}

\section{Climatic impact on egg size}

Egg size in both nautiloids and ammonoids depended on latitudinal changes of climate. The negative relationship between egg size and environmental temperatures (socalled Thorson-Rass rule) is a well known phenomenon

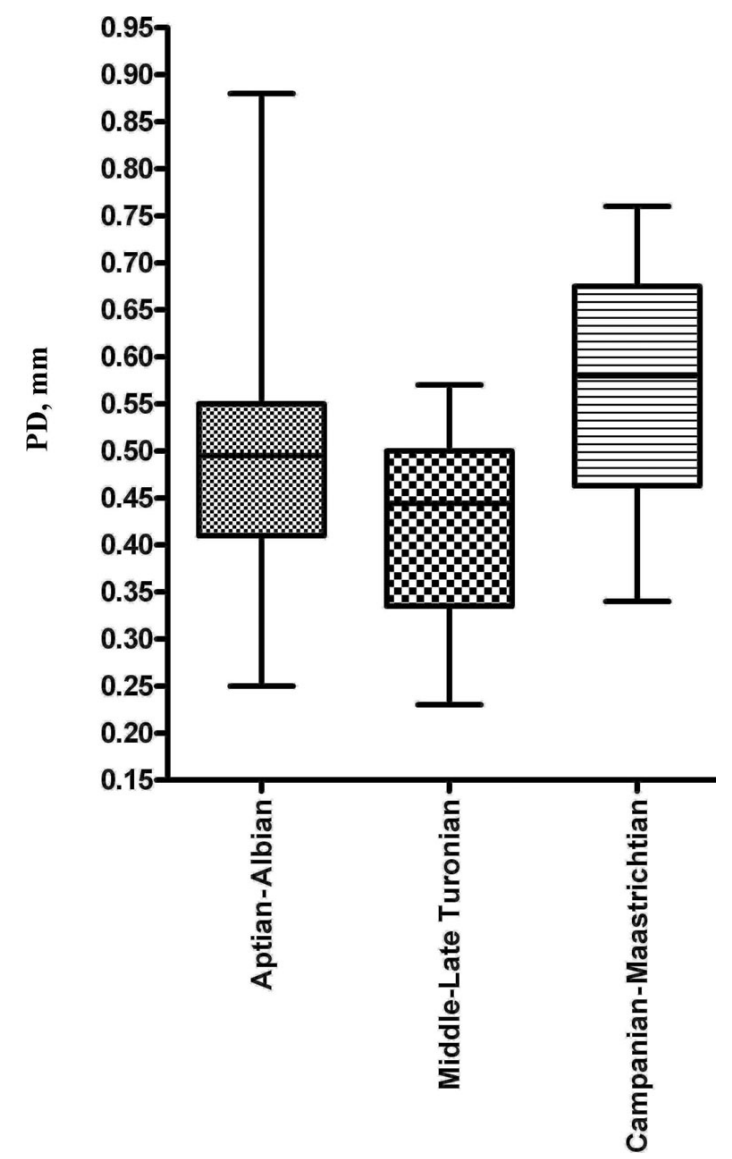

Figure 3. Box plot of Protoconch Diameter in Cretaceous ammonites (min., max., median; the box extends from 25 to 75 percentile).

that exists at both interspecific and intraspecific levels and as phenotypic plasticity (Rass 1935, Thorson 1950, Marshall 1953, Laptikhovsky 2006) but is currently poorly understood. It has been described in extant invertebrates, fish, amphibians and insects, and it can be assumed that similar trends applied in the habitats of the past. Drushchits \& Doguzhaeva (1981) were the first to demonstrate that the ammonitella of Late Mesozoic boreal ammonites were larger than those of warm-water species. Our data on both studied ectocochleate taxa support this suggestion.

However, egg size did not only vary with latitude, but also with global changes in climate. The general decrease in ammonite protoconch size between the Middle and Late Devonian could be explained by climatic change: during this period global temperatures increased (Joachimski et al. 2009) so production of progressively smaller eggs by invertebrates was to be expected. The early Triassic minimum in PD ended with a trend towards increased protoconch size that lasted until the Early Cretaceous. This evolutionary trend coincided with gradual cooling during this period (Barash 2008, Mutterlose et al. 2009; Föllmi 2012) and was particularly marked in high latitudes. During strong Turonian global warming (Takashima et al. 2006) 
ammonite protoconch size decreased, and started to increase again during the gradual Turonian-Maastrichtian cooling.

Egg size of nautiloids was also related to changes in environmental temperatures during geological history and, for example, decreased between the very cold early Permian and the very hot Triassic. However, nautiloid reproductive strategy was probably more dependent on the species' position in trophic webs and other biotic interactions and in contrast to that of ammonoids does not reveal important correlations with global climate changes.

\section{Habitat impact on egg size}

The ecological position of Ammonoidea was not fixed over its evolutionary history, particularly in the late Mesozoic when it was characterised by a gradual shift offshore and into deeper seas (Westermann 1996, Westermann \& Tsujita 1999), possibly away from predatory marine reptiles (Ward 1996). By the end of the Cretaceous most adult stages of ammonites were oceanic to suboceanic (distal neritic), deep epipelagic to mesopelagic and only juveniles occurred in surface waters (Ward \& Bandel 1987, Shigeta 1993, Landman et al. 1996, Moriya et al. 2003, Tajika \& Wani 2011). Evolutionary rates were low, and cosmopolitanism was high - features characteristic of oceanic pelagic deep-water taxa (Ward \& Signor 1983, Ward \& Bandel 1987). This change of habitat during the ecological history of ammonites should obviously have had its impact on reproductive strategy. In Lytoceratina PD increased from Middle Jurassic to Late Cretaceous (Landman et al. 1996). This phenomenon is known but not explained. The same trend might be observed in another ammonite group - Phylloceratina. The general evolution of both taxa was directed to life in ocean depths (Westermann 1996, Westermann \& Tsujita 1999) and in the end of the Cretaceous they inhabited demersal layers of continental slope (Moriya et al. 2003). The fact that these near-bottom ammonites produced much larger eggs than offshore pelagic vertical migrants, Scaphitidae (Westermann 1996, Westermann \& Tsujita 1999) is in agreement with reproductive strategies of extant fish and cephalopods in which a similar trend in egg size exists. Small size of eggs in species reproducing in unstable and unpredictable sub-surface waters is due to increase of mortality at early stages, so - necessity to increase fecundity (Marshall 1953, Nigmatullin \& Laptikhovsky 1994).

There are no indications that coiled nautiloids changed their life style, since post-Triassic nautilids evolved hypoxia tolerance and moved from neritic to slope habitats that is testified by their uncommon occurrence in shallow-water facies and abundance of rhyncholites in deep-water deposits (Riegraf \& Shmidt-Riegraf 1995, Schlögl et al. 2011). Spawning style was not changed either except possibly Aturia in the Palaeocene, just after the extinction of ammonites left a wide range of ecological niches empty in the open ocean. That genus at that time possessed the smallest embryonic shells $(4-5 \mathrm{~mm})$ in the entire history of the coiled nautiloids. Aturia quickly became cosmopolitan, probably because of improved possibilities for juvenile dispersal. This genus was also characterised by the most complex sutures, and an ammonoid-shaped shell (Ward 1980), so it was an evolutionary attempt to restore not just the ammonoid reproductive strategy but the entire life style. However, Aturiacea appeared to not adopt small, ammonite-like eggs. Probably they were similar to the near-bottom shelf-slope predators and scavengers, with their distribution restricted by the need to lay large eggs on the bottom, like "normal" coiled nautiloids.

\section{Ammonoids vs nautiloids - alternative cephalopod reproductive strategies in the past and present}

Earliest evolution of ammonoid reproductive strategies in early - middle Devonian displayed evolutionary trends to decrease in egg size and increase fecundity because of tighter coiling and a size reduction in embryonic shells, ammonitellae (De Baets et al. 2012). Further shift to $r$-strategy in late Devonian was due to changes in protoconch and ammonitela sizes (Landman et al. 1996). Eventually egg dimensions of ammonites became closely resembling those of modern epi-mesopelagic coleoids: the squid families Ommastrephidae, Brachioteuthidae, Enoploteuthidae, Pyroteuthidae, Thysanoteuthidae, Heteroteuthinae, and octopods Argonautoidea, the hatchlings of which are epipelagic (Sweeney et al. 1992). Other extant cephalopods that live either at the bottom or in the meso-bathypelagic layers produce larger eggs (except some dwarfs like Idiosepius). This clearly indicates an epipelagic life style for ammonite juveniles, which is in accordance with suppositions of other authors (Landman 1988, Westermann 1996). Generally, adult ammonites might spawn anywhere, even in deep seas, whereas their hatchlings might quickly rise to surface waters to forage there as happens in the modern abundant and diverse squid families Onychoteuthidae Gonatidae, Cranchiidae and some others (Nesis 1985, 1995). Hypothetically, low positive buoyancy in deep-sea ammonite hatchlings might facilitate such ascension with juveniles automatically achieving neutral buoyancy at the border with the upper, less dense water layer - their natural habitat.

Throughout evolutionary history, nautiloids always produced much larger eggs than ammonoids, with no overlap between these taxa (Ward \& Bandel 1987). Extinct coiled nautiloids normally produced eggs with nauta $>10 \mathrm{~mm}$, and in tropical species nautas could sometimes be extremely large - up to 40-70 $\mathrm{mm}$ with the hatchling size similar to that of many adult ammonites. No vulnerable epipelagic 


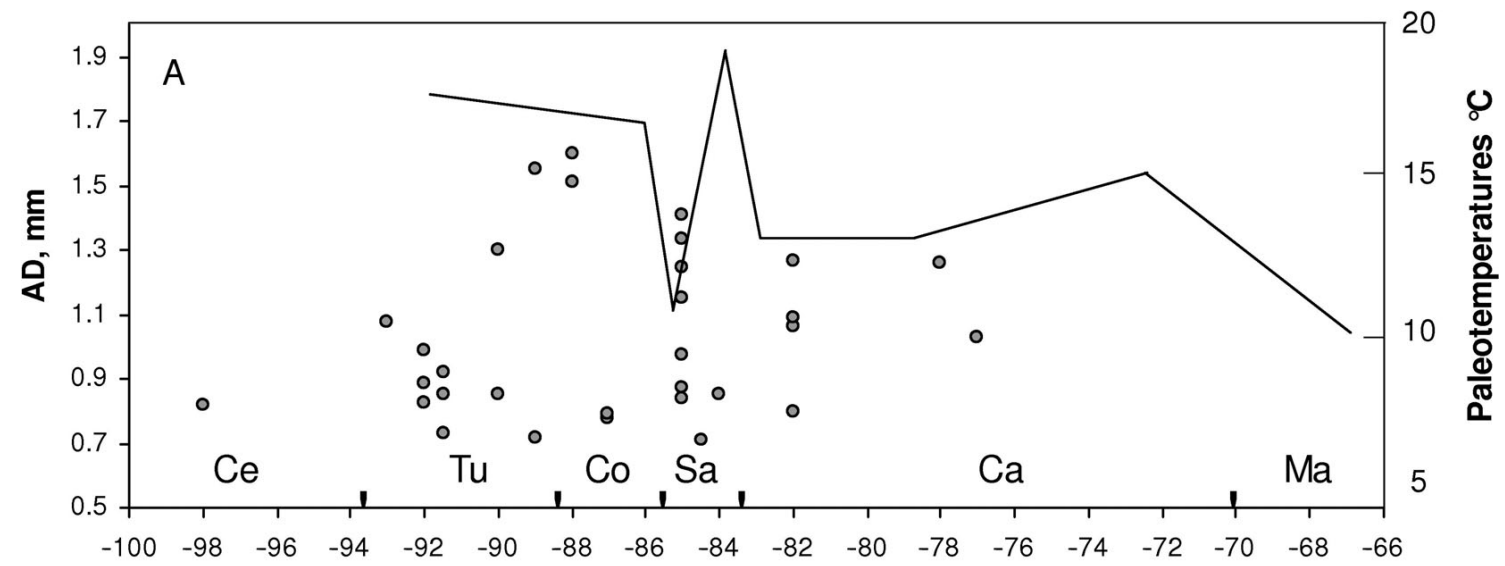

Age, MYA
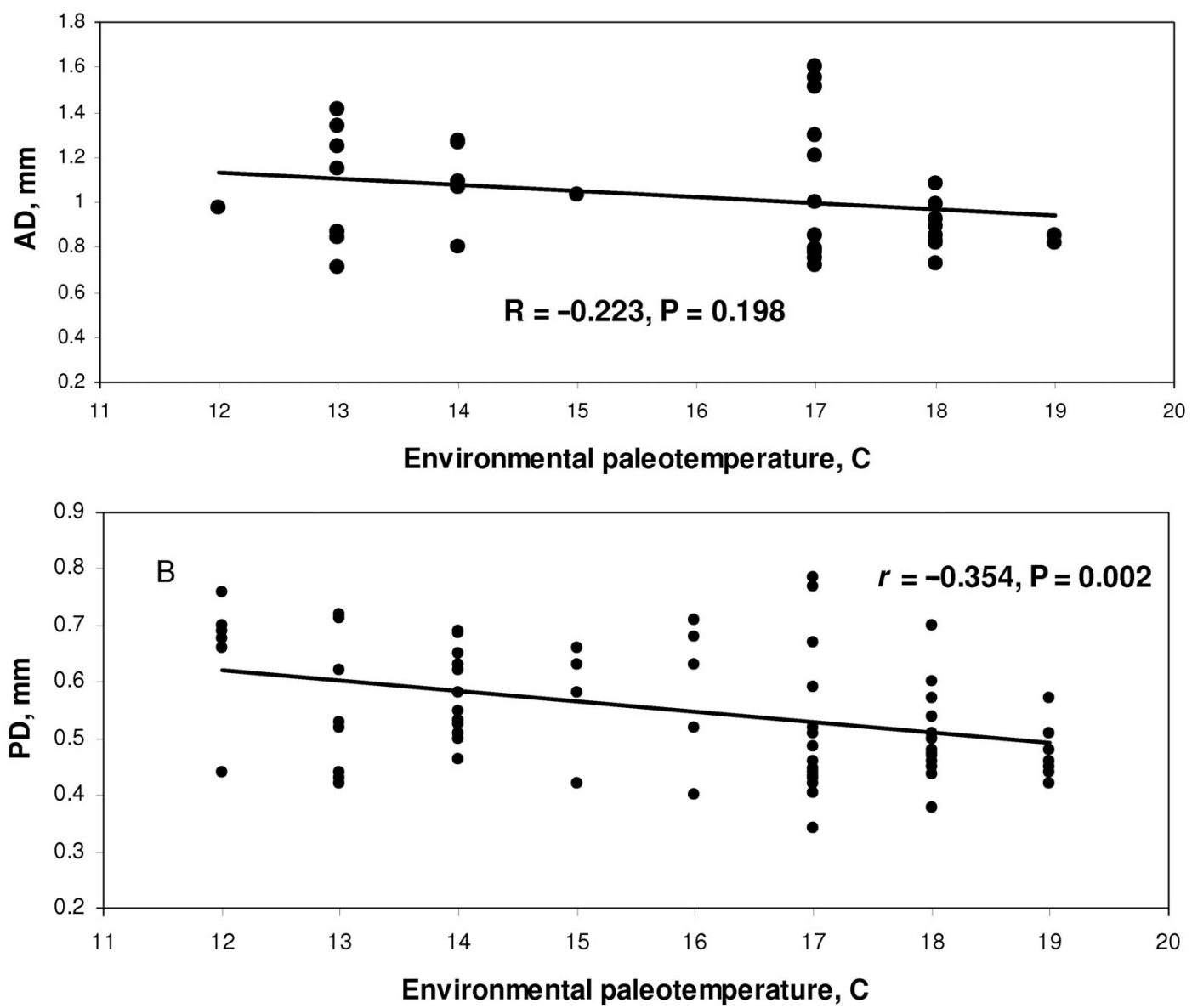

Figure 4. Temporal change of Protoconch Diameter ( $\mathrm{N}=76$; dashed line) in Late Cretaceous ammonoids in North Pacific and paleotemperatures (solid line) in Sakhalin - Hokkaido area estimated from ammonoid shells (Zakharov et al. 1999). A - historical changes, B - correlation.

early stage ever existed, though fecundity was probably low, and juvenile dispersal was restricted. The absence of very large eggs in cold-water nautiloids throughout their evolutionary history seems surprising taking into account the Thorson-Rass rule. It may be explained by the excessive time that would be required for their embryonic development. In modern tropical Nautilus with eggs of moderate size (22-29 mm) embryonic development takes 269-362 days at temperatures $22-24{ }^{\circ} \mathrm{C}$ (Uchiyama \& Tanabe 1999). The development time required for 40-70 mm cephalopod eggs in temperate seas would be unfeasibly long, and would involve too great a risk of predation or destruction. 
Analysis of egg size variation within the $r$ - $K$ continuum in molluscs, echinoderms and fish revealed that there is usually not a taxon-specific modal size somewhere in between the minimum and the maximum, but rather two modes clustering around the extremes (Sewell \& Young 1997, Laptikhovsky 1998, North 2001, Jaeckle 2001). This agrees with the mathematical model of Vance (1973a, b), which predicted that only the extremes in the possible range of egg size and method of nutrition (i.e. planktotrophy, lecitotrophy) are evolutionarily stable strategies. The evolution of reproductive strategies in ectocochleate cephalopods with two modal sizes of eggs (large in Nautiloidea and small in Ammonoidea) perfectly fits this theory.

Small egg size with pelagic offsprings (regardless adult life style and spawning habitat - just like in modern coleoids) allowed ammonoids to occupy surface waters at early ontogenetic stages making juveniles largely independent of near bottom anoxic events (Westermann 1996, Mapes \& Nützel 2009, De Baets et al. 2012). Because of the small eggs, they obviously evolved high fecundity (Landman 1988) to compensate for increasing mortality of a long and vulnerable post-hatching pelagic stage, and high potential for dispersal of early stages by oceanic currents and consequent colonisation of new habitats. These epipelagic planktonic early ontogenetic stages were characteristic of the whole evolutionary history of ammonoids. Species with such a developmental type can maintain gene flow over wider geographic areas, and their populations are supposed to be less subjected to geographic isolation, thus - to allopatric speciation. Because of this it was supposed that sympatric speciation played the principal role in driving their macroevolutionary patterns (Wani 2011).

On the other hand, high fecundity also involves high mortality, thus high selective pressure of the environment and high evolutionary rate because of more intensive elimination of less successful variants. In modern coleoid cephalopods and fish with pelagic eggs and larvae most of this mortality ( $>90 \%$ ) occurs at early stages during the first days and weeks of life (Cushing 1974, Laptikhovsky et al. 1993 and references within). This means that the larval, rather than the adult morphotype, is most strongly subjected to natural selection, which at this stage might switch on such a powerful evolutionary tool as heterochronies (Minelli 2003). Paleozoic ammonoids that survived extinction events generally show novelty in external and internal morphology of the embryonic shell (House 1996) indicating some changes in larval development. An evolutionary increase in egg size could have been a mechanism providing a simple developmental basis for multiple heterochronic changes as an evolutionary response to selection on larval life history traits (Kligenberg 1998 and references within). These developmental changes probably became irreversible in coiled nautiloids that never evolved any small-egged species from late Paleozoic onwards. Natural selection in this group probably most strongly affected animals with adult body morphology.

Because of high evolutionary rates and wide larval dispersal, ammonites were quick to recover after major catastrophes. The entire evolutionary history of ammonoids is a series of major extinction and recovery events, generating a "boom and bust" pattern (McGowan 2004). During the Frasnian-Famennian, Devonian-Mississippian, PermoTriassic, and end-Triassic mass extinctions the ammonoids were almost completely eliminated, but recovered very quickly. After the Permo-Triassic mass extinction it took less than 2 m.y. for a single surviving genus to surpass the biological diversity that had existed prior to the extinction (Brayard et al. 2009), while ammonite recovery after Triassic-Jurassic extinction was even faster (Guex et al. 2012). Eventually ammonites became extinct at the K/T boundary, with a very sudden, major catastrophe that affected oceanic plankton communities. Ammonoidea became extinct together with another dominant small-egged cephalopod group - the coleoid Belemnitida possibly because of oceanic acidification (Arkhipkin \& Laptikhovsky 2012). The most prominent teleost fish that became extinct at the same time were five families that were ecological siblings of modern large-bodied predators like tuna and billfishes (Friedman 2009), which also are small-egged broadcast spawners.

Nautiloids had to lay eggs on the bottom (Chirat 2001, Mapes \& Nützel 2009), and in contrast to ammonoids, had demersal life style from hatching, and did not depend so much on zooplankton (Westermann 1996). Because of demersal spawning nautiloids were restricted in their offshore distribution - ammonites can lay their eggs in pelagic waters above deep seas, whereas nautiloids can not reproduce there. Such an attachment to particular near-bottom habitats probably reduced the evolution of new life styles and it is the most important reason for their lower biological diversity in respect to ammonites. Thus, from the late Paleozoic, nautiloids never developed the morphological diversity seen in the ammonoids from the late Paleozoic to the end of the Cretaceous (Westermann 1996). However, the absence of a vulnerable paralarval stage related to planktonic food webs possibly saved them from extinction at the end of the Cretaceous period. This boundary was also crossed by Sepiida - another large-egged cephalopod group, as well as by squids and octopods. Among fish, the extremely large-egged Elasmobranchii and Coelacanthiformes persisted through $\mathrm{K} / \mathrm{T}$ boundary unharmed as they did through many other extinction events (Laptikhovsky et al. 2010, Wani 2011). Independence of the planktonic food chain was indispensable for long-term survival of taxa.

There is one contradictory case from a "pre-ammonitic epoch" at the Silurian-Devonian boundary of Bohemia, when and where small-egged cephalopods with pelagic 
Table 1. Distribution and occurrence (\% of hauls) of cephalopods with different reproductive strategies over the shelf and slope of Namibia (50-500 m) (from Laptikhovsky 1990). Rare oceanic and deep-sea species removed. Large-egged demersal species are bolded. Upwelling area with intensive inflows of anoxic waters and sporadic occurrence of $\mathrm{H}_{2} \mathrm{~S}$ poisoned mud is shadowed.

\begin{tabular}{|c|c|c|c|c|c|c|}
\hline \multirow{2}{*}{ Species } & \multicolumn{6}{|c|}{ Latitude ${ }^{\circ} \mathrm{S}$} \\
\hline & $17-19$ & $19-21$ & $21-23$ & $23-25$ & $25-27$ & $27-29$ \\
\hline Sepiella ornata & 3.4 & & & & & \\
\hline Sepia bertheloti & 3.4 & & & & & \\
\hline S. elegans & 3.4 & & & & & \\
\hline S. orbygniana & 24.1 & 2.9 & & & & \\
\hline Rondeletiola minor & 17.2 & 2.9 & & & & \\
\hline Alloteuthis sp. & $<0.1$ & $<0.1$ & & & & \\
\hline Loligo reynaudi & 6.8 & 5.8 & & & & 6.6 \\
\hline Illex coindeti & 27.5 & 20.5 & 2.6 & & & \\
\hline Ornithoteuthis sp. & $?$ & $?$ & $?$ & 2.8 & $?$ & $?$ \\
\hline Argonauta nodosa & 3.4 & 8.7 & 5.1 & & & 3.3 \\
\hline Todaropsis eblanae & 24.1 & 26.4 & 33.3 & 2.8 & 2.3 & 10.0 \\
\hline Todarodes angolensis & 31.0 & 64.7 & 61.5 & 38.1 & 50.0 & 23.3 \\
\hline Lycoteuthis diadema & & & & 22.2 & 31.0 & 26.6 \\
\hline Abraliopsis gilchristi & & & & 14.0 & 4.6 & \\
\hline Stoloteuthis leucoptera & & & & & & 3.3 \\
\hline Sepia australis & & & & & & 30.0 \\
\hline
\end{tabular}

offspring performed much better than non-pelagic largeegged cephalopods (Manda 2008, Manda \& Frýda 2010) because of upwelling of anoxic-hypoxic waters. Exactly the same situation exists now on the Namibian shelf and slope, where over a huge area of intensive upwelling between $21^{\circ} \mathrm{S}$ and $27^{\circ} \mathrm{S}$ outbreaks of toxic $\mathrm{H}_{2} \mathrm{~S}$ gas are a seasonally recurrent feature (Emeis et al. 2004). In this area only cephalopods with small pelagic eggs are able to reproduce, whereas to the north and to the south of this, large-egged bottom dwellers are very common (Table 1 from Laptikhovsky 1990 MS). Therefore, such a phenomenon represents a geographical event that has the potential to become a true evolutionary event in the case of global change.

\section{Conclusions}

We may conclude that seawater temperatures were the key factor provoking historical changes in the evolution of ammonoids and nautiloids. Eggs were larger in temperate species with respect to inhabitants of equatorial areas. During global warming egg size decreased, and increased when the Earth's climate became colder. When taxa shifted into deeper and colder habitats during evolution it also provoked an increase in protoconch size: a phenomenon similar to that observed in modern fish and squids. However, in spite of all changes in egg size there were always two non-overlapping strategies in ectocochleate cephalopods. Ammonites never evolved large eggs even in the polar regions, and the smallest known nauta of coiled nautiloids were still 3-4 times bigger in volume than the largest known ammonitella.

Small eggs provide a relatively short-term (in the geological sense) ecological success with high evolutionary rates, biological diversity and the possibility of colonisation of new habitats. Large eggs help taxa to persist through geological history, but at the cost of lower biological diversity, lower evolutionary rates (as demonstrated also by Coelacanthiformes and Elasmobranchia) and less possibility to colonise new habitats, which would obviously be achieved first by small-egged species with a pelagic larval stage. Small-egged and highly fecund species are more vulnerable to disasters of a climatic, or abiotic character (extraterrestrial impact, volcanism, glaciation). Low fecundity, large-egged species are more vulnerable to disasters of ecological, biotic character such as the appearance of new predators. These conditions are still true today with the added impact of human activities.

\section{Acknowledgements}

The authors sincerely thank the Russian Academy of Sciences for RFBR grant No. 09-05-00456 , 10-05-00276, 12-05-00380, Program No. 1 of Earth Sciences division of RAS and Programs of the Presidium of RAS No. 18 and 24 for support, and colleagues at $8^{\text {th }}$ International Symposium, Cephalopods - Present and Past (Dijon, 2010) for fruitful discussion. They are very grateful to K. Tanabe, N. Landman and K. Bandel for valuable and detailed comments on earlier version of the manuscript, and Paul Brewin and Max Barclay for editing the English language. Results of this paper were presented at the $8^{\text {th }}$ International Symposium, Cephalopods - Present and Past, Dijon, August 30-September 3, 2010.

\section{References}

ARKHIPKIN, A. \& LAPTIKHOVSKY, V. 2012. Impact of oceanic acidification on plankton larvae as cause of mass extinctions in ammonites and belemnites. Neues Jahrbuch für Geologie und Paläontologie, Abhandlungen 266/1, 39-50.

DOI 10.1127/0077-7749/2012/0268

BARANOV, V.N. 1985. Ob ostatkah ikry v zhilyh kamerah pozdnevolzhskih ammonitov. Bulletin Moskovskogo Obshchestva Ispytatelei Prirody, Otdel Geologicheskii 60, 89-91.

BARASH, M.S. 2008. Development of Mesozoic ocean biota under influence of abiotic factors. Okeanologiya 48, 583-599.

Brayard, A., Escarguelìz, J., Bucher, H., Monnet, C., Brilhwiler, T., Goudernand, N., Galfetti, T. \& GueXs, J. 2009. Good Genes and Good Luck: Ammonoid Diversity and the End-Permian Mass Extinction. Science 235, 1118-1121. DOI 10.1126/science. 1174638 
Chirat, R. 2001. Anomalies in embryonic shell growth in postTriassic Nautilida. Paleobiology 27, 485-499.

DOI 10.1666/0094-8373(2001)027<0485:AOESGI>2.0.CO;2

Cichowolski, M., Ambrosio, A. \& Concheiro, A. 2005. Nautilids from the Upper Cretaceous of the James Ross Basin, Antarctic Peninsula. Antarctic Science 17, 267-280.

DOI 10.1017/S0954102005002671

Cushing, D.H. 1974. The possible density dependence of larval mortality in fishes, 103-111. In BlaXTER, J.H.S. (ed.) The Early Life History of Fish. Springer-Verlag, New York.

De Baets, K., Klug, C., Korn, D. \& Landman, N.H. 2012. Early evolutionary trends in Ammonoid embryonic development. Evolution 66, 1788-1806. DOI $10.1111 /$ j. $1558-5646.2011 .01567$

Dera, G., Neige, P., Dommergues, J.-L. \& Brayard, A. 2011. Ammonite paleobiogeography during the Pliensbachian-Toarcian crisis (Early Jurassic) reflecting paleoclimate, eustasy, and extinctions. Global and Planetary Change 78, 92-105. DOI 10.1016/j.gloplacha.2011.05.009

Donnadieu, Y., Pierrehumbert, R., Jacob, R. \& Fluteau, F. 2006. Modelling the primary control of paleogeography on Cretaceous climate. Earth and Planetary Science Letters 248, 426-437. DOI 10.1016/j.eps1.2006.06.007

Drushchits, V.V. \& Doguzhaeva, L.A. 1981. Ammonity pod elektronnym mikroskopom. 240 pp. Moscow University Press, Moscow.

Emeis, K.-C., BrÜChert, V., Currie, B., Endler, R., Ferdelman, T., Kiessling, A., Leipe, T., Noli-Peard, K., Struck, U. \& Vogt, T. 2004. Shallow gas in shelf sediments of the Namibian coastal upwelling ecosystem. Continental Shelf Research 24, 627-642. DOI 10.1016/j.csr.2004.01.007

Etches, S., Clarke, J. \& Callomon, J. 2009. Ammonite eggs and ammonitellae from the Kimmeridge Clay Formation (Upper Jurassic) of Dorset, England. Lethaia 42, 204-217. DOI 10.1111/j.1502-3931.2008.00133.x

FöLlMI, K.B. 2012. Early Cretaceous life, climate and anoxia. Cretaceous Research 35, 230-257.

DOI 10.1016/j.cretres.2011.12.005

Frank, S.A. \& SLATKIN, M. 1990. Evolution in a variable environment. American Naturalist 136, 244-260. DOI $10.1086 / 285094$

FRIEDMAN, M. 2009. Ecomorphological selectivity among marine teleost fishes during the end-Cretaceous extinction. Proceeding of National Academy of Sciences (PNAS) 106, 5218-5223. DOI 10.1073/pnas.0808468106

GoLONKA, J. 2007. Late Triassic and Early Jurassic palaeogeography of the world. Palaeogeography, Palaeoclimatology, Palaeoecology 244, 297-307.

DOI 10.1016/j.palaeo.2006.06.041

Gradstein, F.M., OGG, J.G. \& Kranendonk, M. van 2008. On the Geologic Time Scale. Newsletters on Stratigraphy 43, 5-13. DOI 10.1127/0078-0421/2008/0043-0005

Guex, J., Schoene, B., Bartolini, A., Spangenberg, J., Schaltegger, U., O'Dogherty, L., TAYlor, D., Bucher, H. \& Atudorei, V. 2012. Geochronological constraints on post-extinction recovery of the ammonoids and carbon cycle perturbations during the Early Jurassic. Palaeogeography, Palaeoclimatology, Palaeoecology 346-347, 1-11. DOI 10.1016/j.palaeo.2012.04.030
House, M.R. 1996. Juvenile goniatite survival strategies following Devonian extinction events, 163-185. In HART, M.B. (ed.) Biotic Recovery from Mass Extinction Events. Geological Society of London, Special Publication 102.

JAECKLE, W.B. 2001. Variation in the egg size, energy content, and biochemical composition of invertebrate eggs: correlates to the mode of larval development, 49-77. In McEdward, L. (ed.) Ecology of marine invertebrate larvae. CRC Press, London.

Joachimski, M.M., Breisig, S., Buggisch, W., Talent, J.A., Mawson, R., Gereke, M., Morrow, J.R., Day, J. \& Weddige, K. 2009. Devonian climate and reef evolution: Insights from oxygen isotopes in apatite. Earth and Planetary Science Letters 284, 599-609. DOI 10.1016/j.eps1.2009.05.028

Kasyanov, V.L. 1999. Reproductive Strategy in Marine Bivalves and Echinoderms. 229 pp. Oxonian Press, New Delhi.

KLINBERG, C.P. 1998. Heterochroby and allometry: the analysis of evolutionary change in ontogeny. Biological Reviews 73, 79-123. DOI 10.1017/S000632319800512X

KLuG, C. 2001. Life-cycles of some Devonian ammonoids. Lethaia 34, 215-233. DOI 10.1080/002411601316981179

Klug, C., Kröger, B., Kiessling, W., Mullins, G.L., Servais, T., FrÝdA, J., KoRn, D. \& TuRNER, S. 2010. The Devonian nekton revolution. Lethaia 43, 465-477. DOI 10.1111/j.1502-3931.2009.00206.x

Kurushin, N.I. \& ZaKharov, V.A. 1995. Triassic climate in the North Siberia. Bulletin of Moscow Society of Naturalists, Geological series 70, 55-60. [in Russian]

LANDMAN, N.H. 1988. Early ontogeny of Mesozoic ammonites and nautilids, 215-228. In Wiedmann, J. \& Kullmann, J. (eds) Cephalopods - Present and Past. Schweizerbart'sche Verlagsbuchhandlung, Stuttgart.

Landman, N.H., Cobban, W.A. \& Larson, N.L. 2012. Mode of life and habitat of scaphitid ammonites. Geobios 45, 87-98. DOI 10.1016/j.geobios.2011.11.006

LANDMAN, N.H. \& GEYSSANT, J.R. 1993. Heterochrony and ecology in Jurassic and Cretaceous ammonites. Geobios 26, Supplement 1, 247-255. DOI 10.1016/S0016-6995(06)80379-7

Landman, N.H., Tanabe, K. \& Shigeta, Y. 1996. Ammonoid embryonic development, 343-405. In LANDMAn, N., TANABE, K. \& Davies, R.A. (eds) Topics in Geobiology Volume 13. Ammonoid Paleobiology. Plenum Press, New York.

LAPTIKHOVSKY, V.V. 1990. Vidovoy sostav i raspredelenie golovonogih na shelfe i materikovom sklone Namibii. MS stored in VNIERKH 26.01.90 1084-rh90, 20 pp.

LAPTIKHOVSKY, V. 1998. Differentiation of reproductive strategies within a taxon, as exemplified by octopods. Ruthenica 8 , $77-80$.

LAPTIKHOVSKY, V. 2006. Latitudinal and bathymetric trends in egg size variation: a new look at Thorson's and Rass's rules. Marine Ecology 27, 7-14.

DOI 10.1111/j.1439-0485.2006.00077.x

LAPTikhovsky, V.V., ARKhiPkin, A.I. \& Golub, A.A. 1993. Larval age, growth and mortality in the oceanic squid Sthenoteuthis pteropus (Cephalopoda, Ommastrephidae) from the eastern tropical Atlantic. Journal of Plankton Research 15, 375-384. DOI 10.1093/plankt/15.4.375

Laptikhovsky, V., Rogov, M., Nikolaeva, S. \& Arkhipkin, A. 2010. Evolutionary significance of cephalopod egg size dur- 
ing mass extinctions, 66. $8^{\text {th }}$ International Symposium, Cephalopods - Present and Past, University of Burgundy \& CNRS Dijon - France, August 30-September 3, 2010.

MacArthur, R.H. \& WiLson, E.O. 1967. The theory of island biogeography. 203 pp. Princeton University Press, Princeton, New Jersey.

MANDA, Š. 2008. Palaeoecology and palaeogeographic relations of the Silurian phragmoceratids (Nautiloidea, Cephalopoda) of the Prague Basin (Bohemia). Bulletin of Geosciences 83, 39-62. DOI 10.3140/bull.geosci.2008.01.039

MANDA, Š \& FRÝDA, J. 2010. Silurian-Devonian boundary events and their influence on cephalopod evolution: evolutionary significance of cephalopod egg size during the mass extinctions. Bulletin of Geosciences 85, 513-540.

DOI 10.3140/bull.geosci.1174

MAnda, Š. \& TuREK, V. 2011. Late Emsian Rutoceratoidea (Nautiloidea) from the Prague Basin, Czech Republic: morphology, diversity and palaecology. Palaeontology 54, 999-1024. DOI 10.1111/j.1475-4983.2011.01089.x

MAPES, R.H. \& NÜTZEL, A. 2009. Late Palaeozoic mollusc reproduction: cephalopod egg-laying behavior and gastropod larval palaeobiology. Lethaia 42, 341-356. DOI 10.1111/j.1502-3931.2008.00141.x

Marshall, N.B. 1953. Egg size in Arctic, Antarctic, and deep-sea fishes. Evolution 7, 328-341. DOI 10.2307/2405343

McGowan, A.J. 2004. The effect of the Permo-Triassic bottleneck on Triassic ammonoid morphological evolution. Paleobiology 30, 369-395.

DOI 10.1666/0094-8373(2004)030<0369:TEOTPB >2.0.CO;2

MinelLI, A. 2003. The development of animal form: ontogeny, morphology, and evolution. $342 \mathrm{pp}$. Cambridge University Press. DOI 10.1017/CBO9780511541476

Moriya, K., Nishi, H., Kawahata, H., Tanabe, K. \& TakayaNAGI, Y. 2003. Demersal habitat of Late Cretaceous ammonoids: Evidence from oxygen isotopes for the Campanian (Late Cretaceous) northwestern Pacific thermal structure. $G e$ ology 31, 167-170.

DOI 10.1130/0091-7613(2003)031<0167:DHOLCA >2.0.CO;2

Mutterlose, J., Bornemann, A. \& Herrle, J. 2009. The Aptian-Albian cold snap: Evidence for "mid" Cretaceous icehouse interludes. Neues Jahrbuch für Geologie und Paläontologie 252, 217-225.

NESIS, K.N. 1985. Oceanic cephalopod molluscs: distribution, life forms and evolution. 285 pp. Nauka Press, Moscow.

Nesis, K.N. 1995. Mating, spawning and death in oceanic cephalopods: a review. Ruthenica 6, 23-64.

Nigmatullin, C.M. \& Laptikhovsky, V.V. 1994. Reproductive strategies in the squid of the family Ommastrephidae (preliminary report). Ruthenica 4, 79-82.

NoRTH, A.W. 2001. Early life history strategies of notothenoids at South Georgia. Journal of Fish Biology 58, 496-505. DOI 10.1111/j.1095-8649.2001.tb02268.x

PianKa, E.R. 1970. On $r$ - and $K$-selection. American Naturalist 104, 592-597. DOI 10.1086/282697

RAss, T.S. 1935. Geographische Gesetzmässigkeiten im Bau der Fischeier und Larven. Zoogeographica 3, 90-95.

Riegraf, W. \& Shmidt-Riegraf, C. 1995. Mandibula fossiles ammonitorum et nautilorum (Rhyncholithi et rhynchoteuthes, excl. aptychi et anaptychi). In Westphal, E. (ed.) Fossilium
Catalogus. I: Animalia. Pars 134. 219 pp. Kugler, Amsterdam.

Ross, C.A., Moore, G.T. \& Hayashida, D.N. 1992. Late Jurassic paleoclimate simulation - paleoecological implications for Ammonoid provinciality. Palaios 7, 487-507.

DOI $10.2307 / 3514847$

Schlögl, J., Chirat, R., Balter, V., Joachimski, M., HudáČKovÁ, N. \& Quillévéré, F. 2011. Aturia from the Miocene Paratethys: an exceptional window on nautilid habitat and lifestyle. Palaeogeography, Palaeoclimatology, Palaeoecology 308, 330-338. DOI 10.1016/j.palaeo.2011.05.037

Seilacher, A. \& Labarbera, M. 1995. Ammonites as Cartesian divers. Palaios 10, 493-506. DOI 10.2307/3515089

Sewell, M.A. \& Young, C.M. 1997. Are echinoderm egg size distribution bimodal? Biological Bulletin 193, 297-305. DOI 10.2307/1542932

SHIGETA, Y. 1993. Post-hatching early life history of Cretaceous Ammonoidea. Lethaia 26, 133-145. DOI 10.1111/j.1502-3931.1993.tb01804.x

SHIMANSKI, V.N. 1975. Melovye Nautiloidei [Cretaceous Nautiloids]. Paleontologicheskii Institut, Trudy 150, 1-208.

SlatKIn, M. 1974. Hedging ones evolutionary bets. Nature 250, 704-705. DOI 10.1038/250704b0

Stearns, S.C. 1992. The evolution of life histories. 249 pp. Oxford University Press, Oxford.

Stephen, D.A. \& StAnton, R.J. JR. 2002. Impact of reproductive strategy on cephalopod evolution. Abhandlungen der Geologischen Bundesanstalt 57, 151-155.

Sweeney, M.J., Roper, C.F.E., Mangold, K.M., Clarke, M.R. \& BoletZKY, S.V. 1992. "Larval" and juvenile cephalopods: A manual for their identification. Smithsonian Contributions to Zoology 513, 1-282. DOI 10.5479/si.00810282.513

TAJIKA, A. \& WANI, R. 2011. Intraspecific variation of hatchling size in Late Cretaceous ammonoids from Hokkaido, Japan: implication for planktic duration at early ontogenetic stage. Lethaia 44, 287-298. DOI 10.1111/j.1502-3931.2010.00242.x

Takashima, R., Nishi, H., Huber, B.T. \& Leckie, M.R. 2006. Greenhouse world and Mesozoic ocean. Oceanography 19, 82-92. DOI 10.5670/oceanog.2006.07

TeICHERT, C. 1967. Major features of cephalopod evolution, 162-210. In TeIchert, C. \& Yochelson, E.L. (eds) Essays in Paleontology and Stratigraphy. Department of Geology, University of Kansas, Special Publication 2.

Thorson, G. 1950. Reproductive and larval ecology of marine invertebrates. Biological Reviews 25, 1-45. DOI 10.1111/j.1469-185X.1950.tb00585.x

Uchiyama, K. \& TAnabe, K. 1999. Hatching experiment of Nautilus macromphalus in the Toba Aquarium, Japan, 13-16. In Oloriz, F. \& Tover, F. (eds) Cephalopods - Present and Past. Kluwer Academic/Plenum Pub., New York.

VANCE, R.R. 1973a. On reproductive strategies in marine benthic invertebrates. American Naturalist 107, 339-352. DOI $10.1086 / 282838$

VANCE, R.R. 1973b. More on reproductive strategies in marine benthic invertebrates. American Naturalist 107, 353-361. DOI $10.1086 / 282839$

Wani, R., Kurihara, K. \& Ayyasami, K. 2011. The large hatchling size in Cretaceous nautiloids persists across the endCretaceous mass extinction: new data on Hercoglossidae 
hatchlings. Cretaceous Research 32, 618-622.

DOI 10.1016/j.cretres.2011.01.001

WARD, P. 1980. Comparative shell shape distributions in Jurassic-Cretaceous ammonites and Jurassic-Tertiary nautilids. Paleobiology 6, 32-43.

WARD, P.D. 1996. Ammonoid extinction, 815-824. In LANDman, N.H., Tanabe, K. \& Davis, R.A. (eds) Topics in Geobiology. Vol. 13, Ammonoid Paleobiology. Plenum Press, New York.

WARD, P.D. \& BANDEL, K. 1987. Life history strategies in fossil cephalopods, 329-350. In Boyle, P.R. (ed.) Cephalopod life cycles, Vol. 2. Comparative Reviews. Academic Press, London.

WARD, P.D. \& SignoR, P.W. 1983. Evolutionary tempo in Jurassic and Cretaceous ammonites. Paleobiology 9, 183-198.

Westermann, G.E.G. 1996. Ammonoid life and habitat, 607-707. In Landman, N., Tanabe, K. \& Davies, R.A. (eds)
Topics in Geobiology. Vol. 13, Ammonoid Paleobiology. Plenum Press, New York.

Westermann, G.E.G. \& Tsujita, C.J. 1999. Life habits of ammonoids, 299-325. In SAVAzZi, E. (ed.) Functional morphology of invertebrate skeleton. John Wiley \& Sons Ltd.

Wierzbowski, H. \& Rogov, M. 2011. Reconstructing the palaeoenvironment of the Middle Russian Sea during the Middle-Late Jurassic transition using stable isotope ratios of cephalopod shells and variations in faunal assemblages. Palaeogeography, Palaeoclimatology, Palaeoecology 299, 250-264. DOI 10.1016/j.palaeo.2010.11.006

Zakharov, Y.D., Boriskina, N.G., Ignatyev, A.V., TANabe, K., Shigeta, Y., Popov, A.M., Afanasyeva, T.B. \& Maeda, H. 1999. Palaeotemperature curve for the Late Cretaceous of the northwestern circum-Pacific. Cretaceous Research 20, 685-697. DOI 10.1006/cres.1999.0175 